John Bintliff

\title{
Spatial analysis of past built environments: Houses and society in the Aegean from the Early Iron Age till the impact of Rome'
}

\begin{abstract}
Between ca. Ioo० BC, the Early Iron Age, and the Roman Late Republican era ca. Ioo BC, domestic life in Greece changed in remarkable ways. On one level we see a process of continual elaboration, confirming Susan Kent's (Kent I990) generalization that growing complexity in the built environment can form a mirror for that in contemporary social and political life. Yet in parallel we can also see a cycle, beginning with a largely undifferentiated and simple domestic environment matched by the larger residences of an elite, passing through a period when relative equality becomes the norm, then returning to an era where class differences in homes are striking. The Greek house is thus a barometer for the longer-term transformations in social life as a whole.
\end{abstract}

\section{Introduction}

As a specialist in material culture, I would like to explore the theme of 'communal values', through the evolution of house and town planning in the Greek city, summarizing recent work by various authors, and using the simplest form of Space Syntax - Access Analysis (Hillier and Hanson I984; Hillier I996). The theoretical and more importantly the empirical underpinnings of Space Syntax are elegantly summarized in Bill Hillier's chapter in this volume, while much more sophisticated combinations of built-space investigation where access-analysis is complemented by other methodologies such as viewsheds are to be found in the chapters by Fisher, Hacigüzeller and Thaler, and Stöger. Nonetheless since this paper is a presentation and discussion of recent work on ancient Greek towns, in which these more elaborate techniques are only just being applied, it seems worthwhile to demonstrate how remarkably effective even access analysis can be when brought together with a rich archaeological, artistic and contemporary literary corpus for relating social change to the dynamics of the built domestic environment.

\section{Iron Age beginnings}

In the Iron Age we find two recognized settlement types (Snodgrass I980; I991; Morris I99I; 2000; Lang I996; Mazarakis-Ainian I997). The first is a scattered village plan, such

I The analysis in this paper is explored in more detail in Bintliff (20I2). 

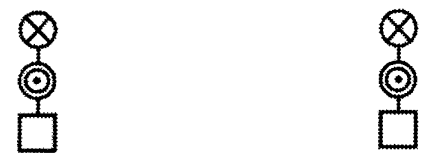

Nichoria IV
Figure 1 | Access and function diagrams for typical house plans of Early Iron Age Greece. The upper image shows access, the lower one depicting room arrangements. Key: crossed circle is the entrance, double circle is a room with 2 access points, empty circle is a room, dotted circle is the smallest room, empty square largest rooms (from Lang Emporio, Megaron 2005, p.24).

as has been excavated underneath the later city of Eretria. Domestic dwellings are dispersed and disorganized with regard to each other. Houses are frequently just a single room, such as was discovered at Old Smyrna. However, several settlements appear to show a chieftain's greathouse/communal focus amidst them. The best-known example is Lefkandi. Lang (2005) has deployed Access Analysis in the typical family home. Movement into and through these houses is extremely basic, a simple sequent access route (fig. I).

Only the rare chief's house offers slightly more complex internal space, but this also follows a linear progression of rooms. The small scale of the normal dwellings indicates that everyday life was carried out largely outside in communal view, in contrast to the large central rooms of the chieftain's dwellings, assumed to be used for feasts and other communal activities. The majority social group of peasants clearly required no significant differentiated house spaces for their social or economic lifestyle.

The other form of Early Iron Age community can be described as more townlike. This is made up of close clusters of the previously discussed unplanned hamlets, each with their own cemeteries and presumed chiefs (basileis). The best-known examples are Athens and Argos. The multiple foci are assumed to reflect settlements of agglomerated chieftaincentred hamlets, run by a competitive oligarchy.

'Dark Age' society is believed to be dominated by the strong control over peasants by chiefs and a middle class farming group (Morris 1987). The dependence on individual leaders, more 'Big Men' than hereditary aristocratic dynasties, may account for the relative mobility of the smaller of the two settlement forms described above.

Nevertheless, notably towards the end of the protohistoric era, there are occasional experiments with formal planning of such minor communities. One striking example is the site of Vroulia (fig. 2), which although likely to be set out under elite direction, appears in its regimented rows of 'citizen's houses' to reflect the same concepts which were underlying the contemporary rise of the larger city-state or polis as a corporate community of occupants (Lang 1996). 


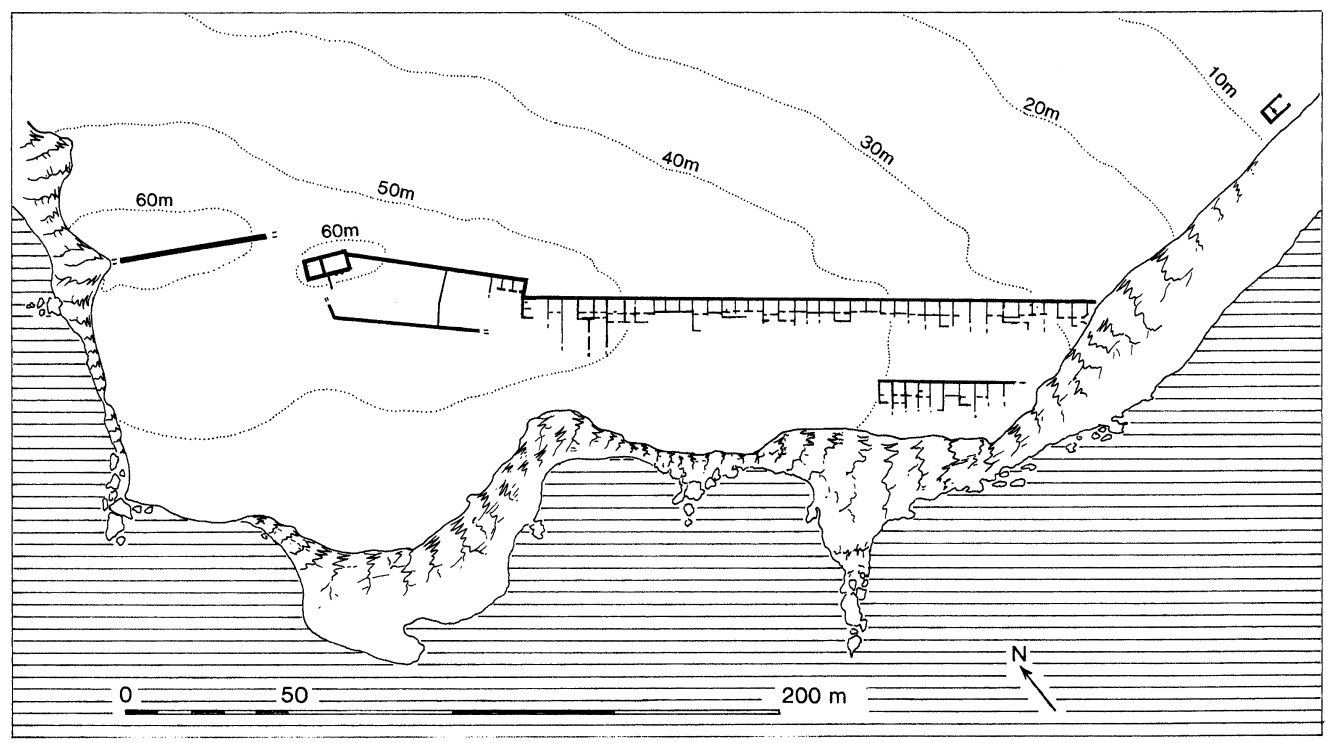

Figure 2 | Plan of the final Iron Age, transitional Archaic settlement of Vroulia on Rhodes (from Whitley 200I, p. I72).

The explosion of city-states across the Aegean between 800 and 500 BC is an extraordinary phenomenon. Hansen (2004) and Ruschenbusch (1985) have shown that the typical polis was surprisingly small, 2000-4000 citizens, arising as nucleated, introverted 'corporate communities' over tiny territories, in which dependent villages and farmsteads clustered around an urban focus, where generally 70 to $80 \%$ of the population resided.

It was the historical geographer Ernst Kirsten (Kirsten I956; cf. Bintliff I994), who recognized that this evolution gave birth to the normal Greek polis as a 'village-state' (Dorfstaat), whilst a very small minority of city-states reached far greater population, his 'Megalopoleis', which were territorial states and generally included other towns in their regions or empires. Notable megalopoleis in the Aegean were Athens and Thebes.

\section{The Archaic era}

The rise of the city-state or polis, out of these fragmented settlements, can in part be accounted for through population growth, creating their fusion into single integrated settlements, but is as much due to major social change, resulting from the decline of the elite grip on the community matched by increasing legal and political rights for all free male citizens. A case can still be made that the broadening of citizen's rights is linked with military reforms, notably the growing centrality of the essentially middle-class citizen-army or hoplite warfare to the city-state. In any case, the Archaic era sees the generalized erosion of 

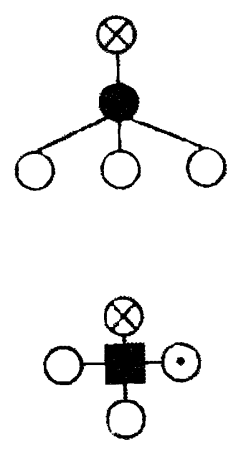

Figure 3 | Access and function diagrams for more elaborate houses at Zagora on Andros, from the transitional Iron Age/Archaic period. The upper image shows access, the lower one depicting room arrangements. Key: crossed circle is the entrance, filled square is the largest room serving as transitional areas; empty circles are rooms, dotted circle is the smallest Zagora $G \quad$ room (from Lang 2005, p. 24).

the power of the aristocratic basileis in favour of the middle class, and in varying degrees towards the free peasant class. By Classical times, perhaps half of the city-states in the Aegean had adopted what we might term a 'moderate democracy'.

These major sociopolitical changes can be seen in material form when we return to the evidence from private house architecture and town-planning (fig. 3). Already from final Geometric and early Archaic times (the $8^{\text {th }}$ to $7^{\text {th }}$ centuries) we can see the elaboration of family homes, expanding the number of rooms and enclosing partly or wholly the outside working areas, to construct a more focussed, private citizen-family residence reflecting a sense of growing importance for this basic constituent of the emergent city-state or polis. The last phases of the settlement at Zagora on Andros exhibit this trend well, as can be seen both in its increasingly complex plan and in the more elaborate house access diagrams. At first such sprawling room-complexes may represent clusters of related families gaining more privacy, but over time these simplify into the small, more coherent, radially planned regular room-groups arrayed around a private courtyard, which we can later associate with the nuclear or extended citizen family.

However, the remainder, some half of Greek societies, were not to adopt democracy, remaining under aristocrats, even kings, or in a form reminiscent of, and perhaps merely perpetuating, the South Aegean Dark Age model, where a large serf population is dominated by an equally large body of middle and upper class citizens. This latter model is bestknown from Thessaly, and from Doric states such as Sparta and the city-states of Dorian Crete. It is of great interest to see what changes in the settlement plan and then in the domestic house occur in these politically conservative 'serf' societies from Archaic into Classical times.

Haggis (2007) has used a detailed regional survey and excavation at the emergent citystate of Azoria in Crete to trace the material evidence for the creation of this distinctive form of Dorian serf-state in Archaic to Classical times. Firstly there is clearly a rise in population and wealth, as well as nucleation into a series of city-state centres. Rich tombs, as generally 

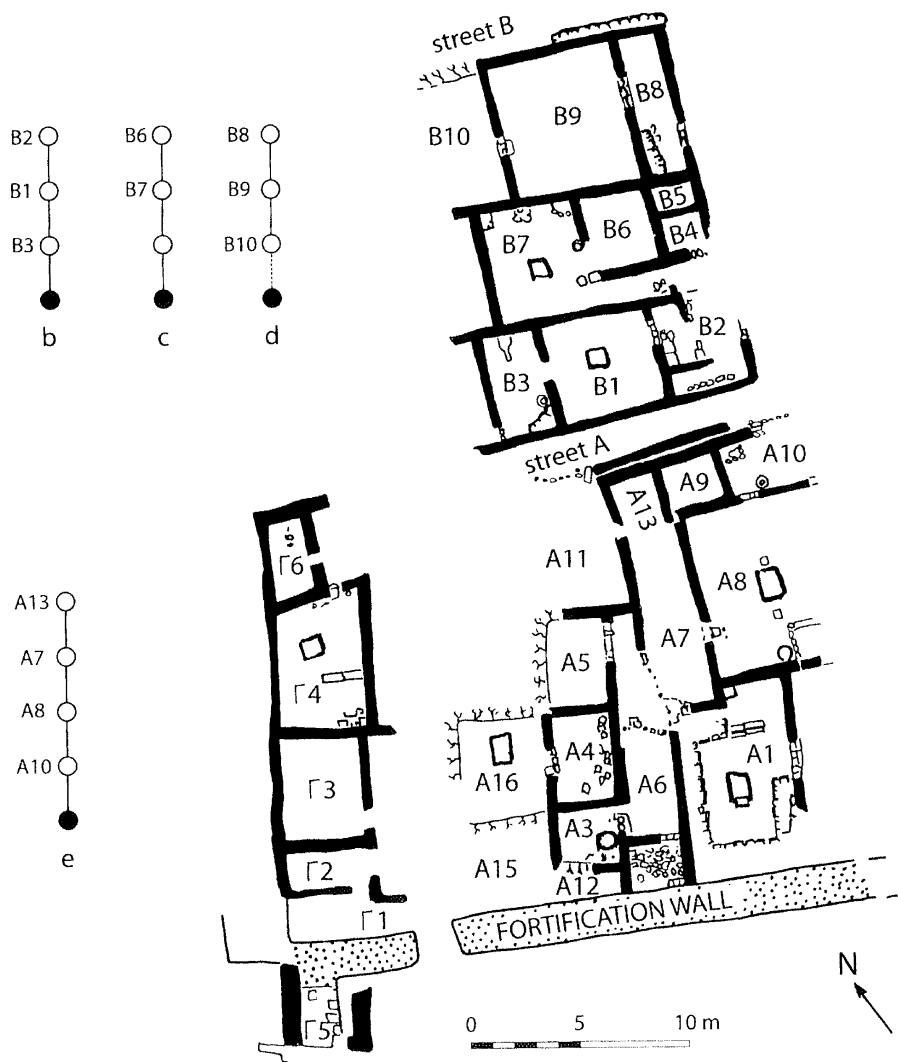

Figure 4 | Typical houses at the Cretan early Hellenistic settlement of Trypetos, Crete. Outside space in the house access diagrams are shown as dark circles, whilst the simple linear sequence of rooms is shown as clear circles (from Westgate 2007, p. 438).

in the Southern Mainland of Greece, decline as prestigious objects are redirected into temple offerings, a sign of the creation of a civic identity and the decline of aristocratic power in favour of a broad middling-citizen community. Yet the similarity to the trajectory leading to Greek democracy is then frozen at this point of evolution. The public monumental city-centre, although including the customarily prominent Agora and major temple, also contains complexes for the storage, preparation and communal consumption of food by the male citizen community (the andreion or syssitia).

At the Cretan town of Trypetos (Westgate 2007) Early Hellenistic private homes show two significant features (fig. 4). On the one hand, the houses are multi-roomed, continuing the trend we witnessed generally from the late Iron Age towards elaboration of the family home. But equally notable is the fact that most houses have simple linear access, being relatively open to the neighbours and the rest of the community. 


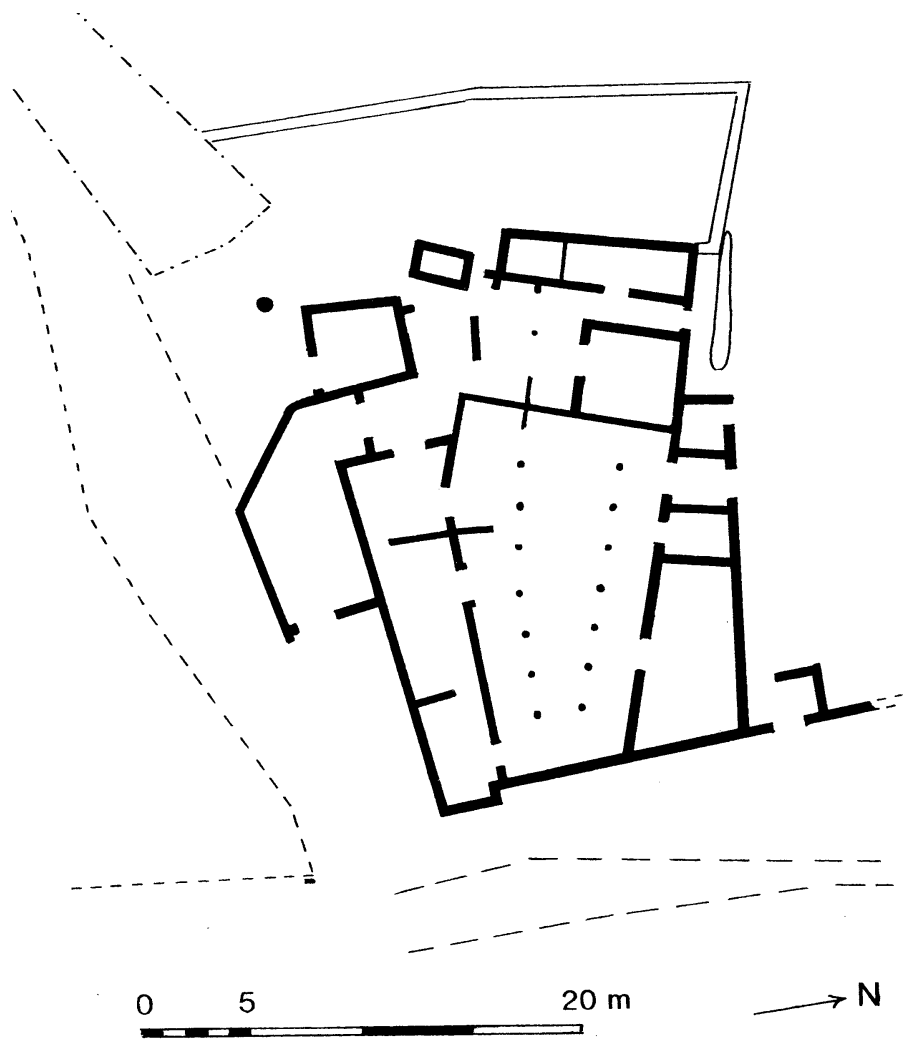

Figure 5 | Archaic Mansion, Building F from the surroundings of the Athenian Agora (from Whitley 200I, p. I73).

If we compare the indications from Azoria and Trypetos, the growth of family prosperity at least for the citizens, but moderated by the centrality of communal life, appears well expressed in the contemporary designs of private citizen's homes. The diversion of male citizen life into centralized dining complexes in the town freezes the elaboration of the domestic house after its initial unfolding into several spaces, preventing the emergence of a closed and private family focus, and marginalizing the non-adult male members of the citizenry.

Although at one level the rise of the city-state is seen to stimulate an elaboration of typical domestic spaces, whether in rising democracies or in conservative serf-states, at least till the end of Archaic times aristocrats were still dominant in most Greek states. One example of a likely elite mansion is a building discovered on the fringes of the Athenian Agora (fig. 5). 


\section{The Classical era}

In general, by and during Classical times, urban settlements in southern Greece evolve in two ways.

Older settlements simply grew, either through the infilling of former hamlet clusters, or expanding out from single cores (Snodgrass I99I), but organically and with poor articulation. Athens was to contemporaries a notorious example of an unplanned town, except for its public spaces. These focussed on a symbolic communal ritual centre (the Acropolis) and a large open space for public gatherings, enhanced commerce as well as public facilities such as parliament buildings, law courts and city record offices (the Agora).

For these long-established towns, we have too little house evidence to confirm our textual sources, which suggest a likely decline within the moderate to full democracies of large elite dwellings, and a general flattening of house display both externally and internally, conforming to a principle of relative citizen equality. But the limited examples of excavated homes which we do have show a very widespread form, the multi-roomed courtyard house, both in the Aegean non-serf-states and in colonies abroad, which can be read as expressing this concept. Some differences in known examples, such as we see in the next figure (fig. 6), allow us to infer distinctions presumably based on simple relative wealth, between larger and smaller versions of this plan, marking what we might suppose is the typical middle-class version, and the poor in smaller stripped-down versions. Intelligent analysis by Jameson (I990; I990a) of the most typical scale of courtyard-house, some 200 to 300 square metres in size, suggests that the design was intended for a nuclear family plus a slave or two.

The emphasis is on enhancement of the private citizen family: the front door shuts out the wider community, then (fig. 7) multiple room spaces are radially accessed from the focal enclosed courtyard. This open space appears as a major locale for work, ritual and familial socialization, thus for varied social and economic roles. After lengthy debates on the presence, absence and possible location of 'female quarters', it now seems widely agreed that almost the entire walled house now appears to have become a women's space, contrasted to that of the male, which was the public extramural world of the assembly, law courts, gymnasium etc.

In new planned settlements, of which the best-known architecturally is Olynthus (Cahill 2002), it was possible to underline citizen-equality by the construction in perfect symmetry of apparently uniform house blocks of this single-entrance courtyard type, seen as the materialization of isonomia (citizen equality). Some new towns, such as Piraeus, subordinate the planning of public spaces to the grid of blocks of domestic housing, as if the latter were now the central concept of town organization, followed in second place by good communication infrastructures in and out of town (to facilitate citizen movements to farm-estates forming the town's hinterland or to port facilities). 


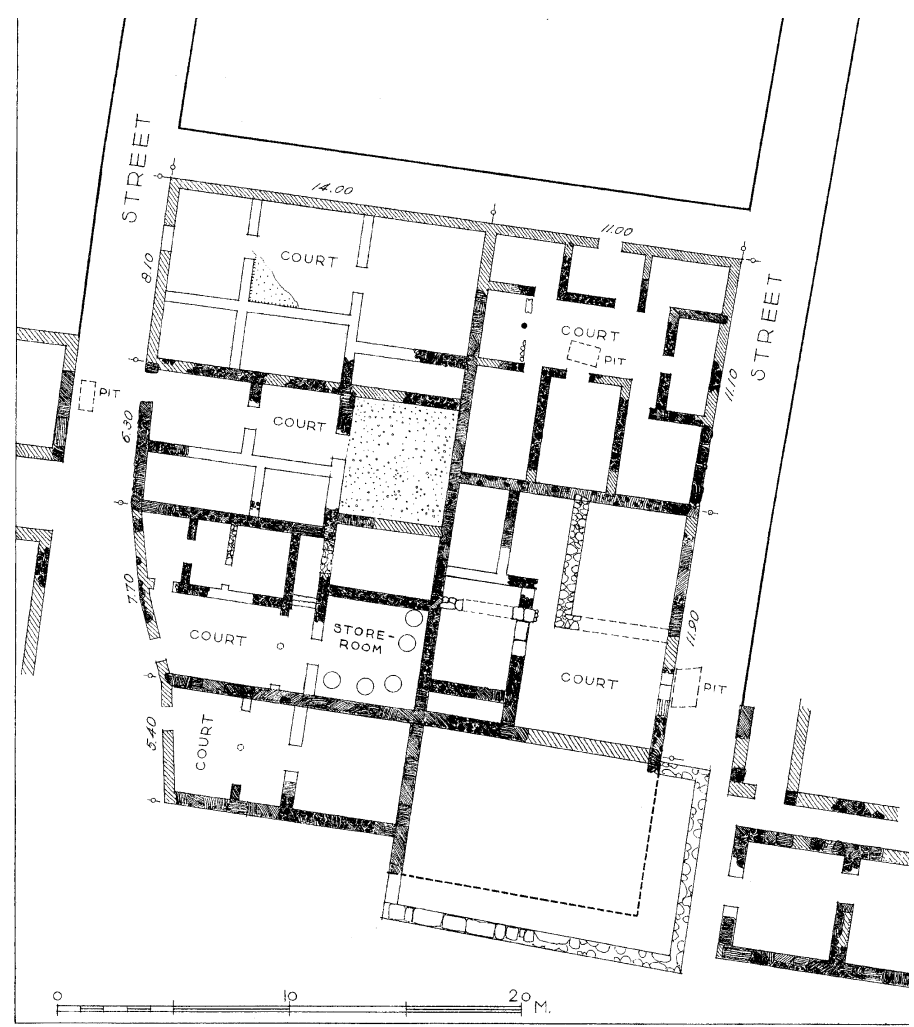

Figure 6 | Classical Houses at the north foot of the Areopagus Hill, Athens. Each house is identified by its courtyard, showing variability in the size of small to medium-sized houses (from Tsakirgis 2005, p. 68).

However, inscriptions show that house values range considerably for similarly sized properties, unsurprisingly affected by more or less desirable locations within the city (Cahill 2002). Moreover, texts allow us to infer that the very concealed nature of house-internal arrangements could allow families of wealth and status to advertise themselves away from the public eye, through luxurious house furnishings, wall-paintings and table-vessels of precious metal, thereby erecting a parallel value system to the apparent housing democracy. In the same way, town-quarter analysis at Olynthus (Cahill 2002) has made clear that houses with superficially similar plans could conceal contrasted economies, made clearer by the study of house contents (in this case differences between streets of artisans and those of the owners of larger agricultural estates).

The importance of restraint on ostentatious displays of wealth in the city-state can finally be illustrated by the lack of restrictions when we turn to remoter rural areas far from the town. In the Athenian village of Atene, the majority of Classical estate-centres are medium to large establishments, with only a few small 'peasant family farms' (Lohmann I993). 

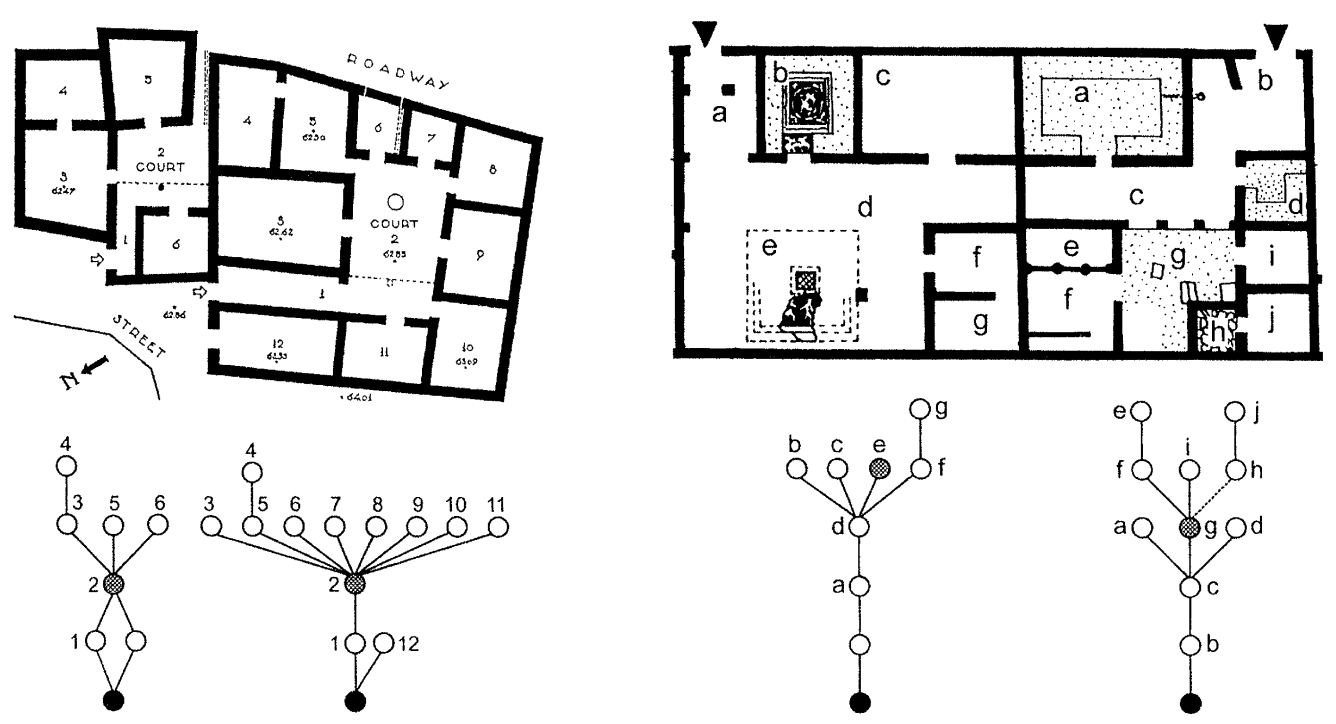

a

b

Figure $7 \mid$ (a) $5^{\text {th }}$ century BC houses near the Agora, Athens (Houses C and D). (b) Houses at Olynthus, late $5^{\text {th }}-$ early $4^{\text {th }}$ century BC. Outside space in the house access diagrams are shown as dark circles, courtyards as grey circles, and individual roofed rooms as clear circles (from Westgate 2007, p. 425).

Already by late Classical times the decay of community politics was associated by contemporaries (such as Demosthenes) with the urban rich constructing more prestigious townhouses.

\section{Hellenistic and Early Roman eras}

Alexander the Great's conquests led to the relatively-fixed large kingdoms of Hellenistic times, causing the rapid death of the autonomous city-states and, with it, of the concept of citizen equality. The decline of the democratic city-state is symbolized by changes in the public and private sphere. Public spaces such as the Agora become filled with prestigious monuments to display the acquisition of absolute power by the city's rich, and by external kings and princes. Political activity is increasingly moving to giant palatial complexes at the heart of new large dynastic states, reducing polis politics to local issues. Even these palaces of the Greek dynasts are largely a series of giant reception rooms for hosting social events for the display and negotiation of power, with private accommodation and government offices relegated to the periphery of the plan (Étienne and Müller et al. 2000). This pattern was set early in the originating kingdom for the Hellenistic world, that of Macedon, and is well illustrated by the royal palace of Aegai (fig. 8). Such elite palaces are arguably emulated 


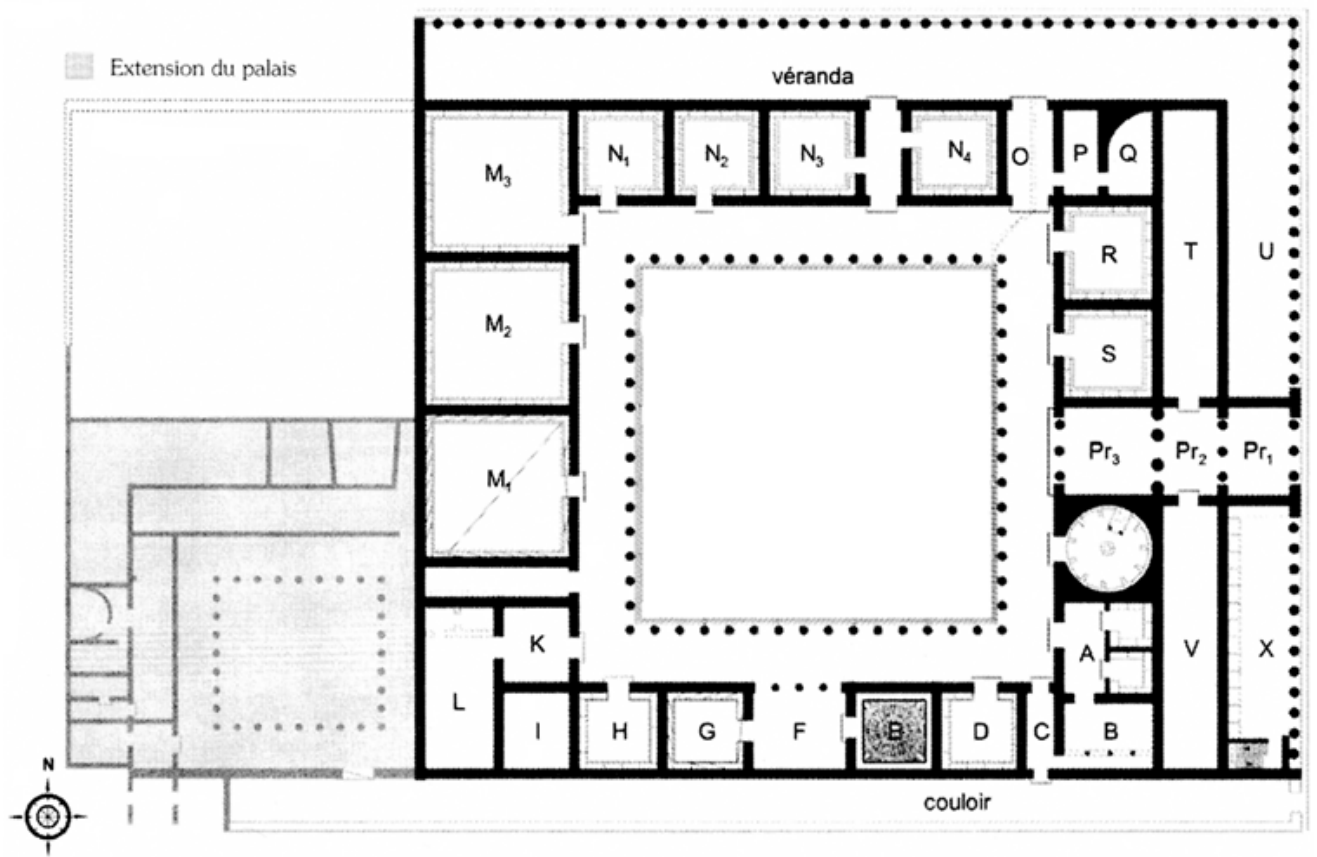

Figure $8 \mid$ The palace of the kings of Macedon at Aegai-Vergina, $4^{\text {th }}$ century BC (from Étienne et al. 2000, fig. II3).

in the new semi-public form of the homes of the better-off citizens of the Hellenistic world. Not surprisingly early examples of these 'trickle-down' effects are found in the new Macedonian capital city of Pella, where urban mansions with multiple courts, ornamented by columned porticoes (peristyles) and mosaics, have been excavated.

The reduction of a meaningful political role for the average male citizen in the Greek city-state had several effects. Networking with the new powerful elites to whom local power is entrusted by the Hellenistic monarchs, and a concern with advertising and improving family status socially and economically, converts the former closed-in world of the house the 'oikos' - to a semi-public sphere, at least for the middle to upper classes. The traditional private family courtyard with its radiating rooms is supplemented or replaced by a display court with several reception rooms, often highly decorated. The House of the Mosaics at Eretria (fig. 9) is an early example of this development (Nevett I999). Peristyles around such courts may be accompanied by fountains and statuary, and these 'display courts' can even be the first complex encountered when coming from the street (fig. Io). The access diagrams for such homes (Westgate 2007) illustrate the marginal location of their private and service rooms, requiring complex indirect pathways to reach them, compared to the directly accessible and focal semi-public visitor-reception court and diningrooms. 


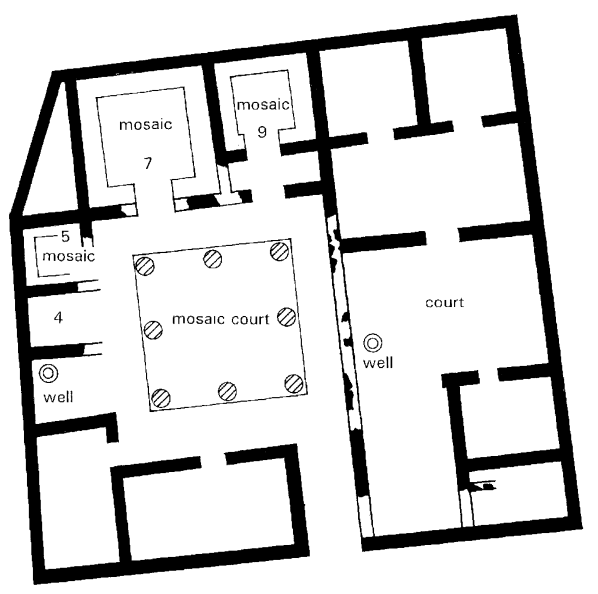

Figure 9 | House of the Mosaics, Eretria, $4^{\text {th }}$ century BC (from Nevett I999, p. I09).
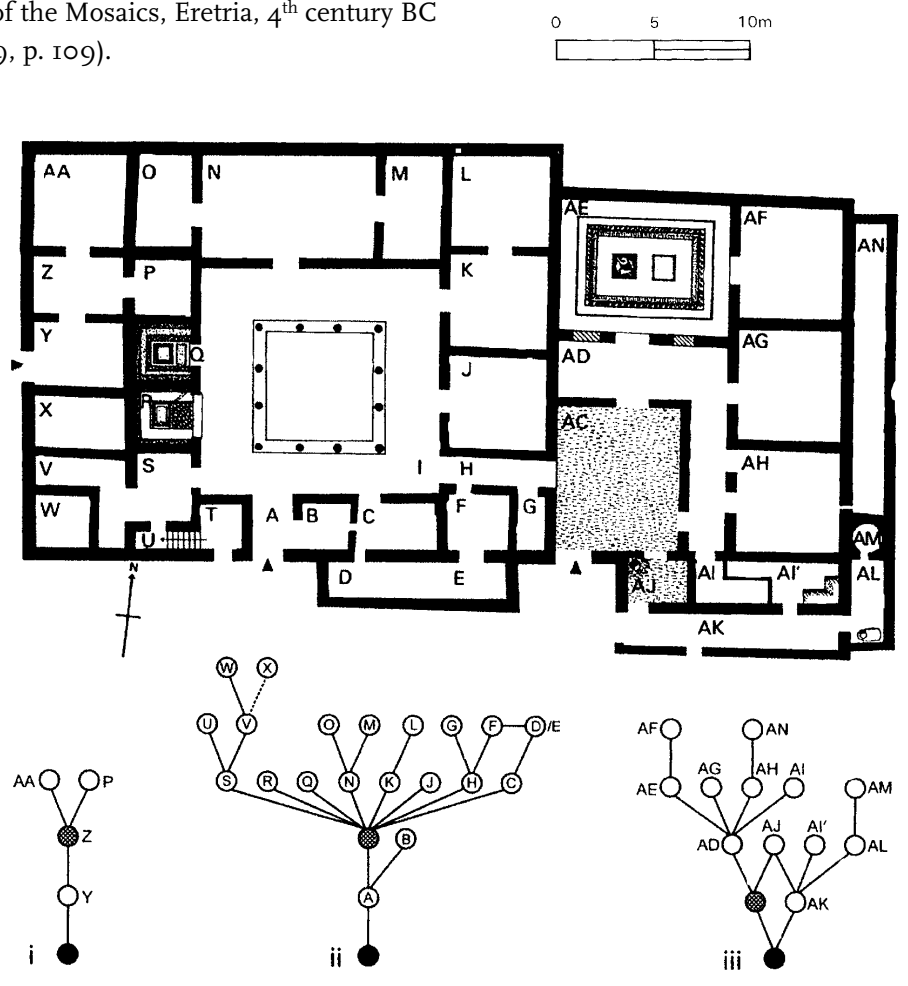

C

0 $20 \mathrm{~m}$

Figure 10 | Late Hellenistic houses from Delos. Outside space in the house access diagrams are shown as dark circles, courtyards as grey circles, and individual roofed rooms as clear circles (from Westgate 2007, p. 425). 


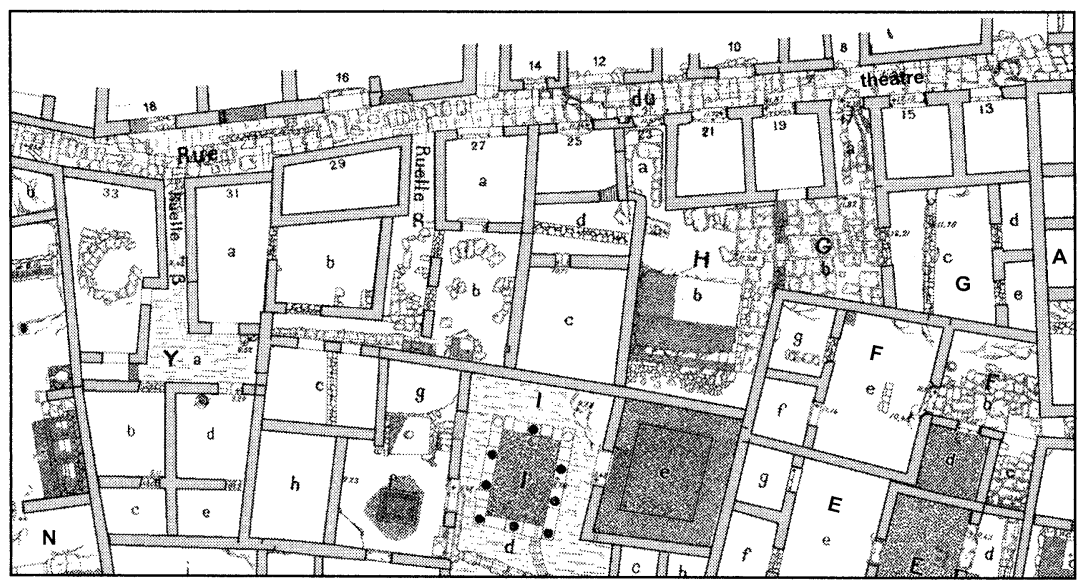

a.
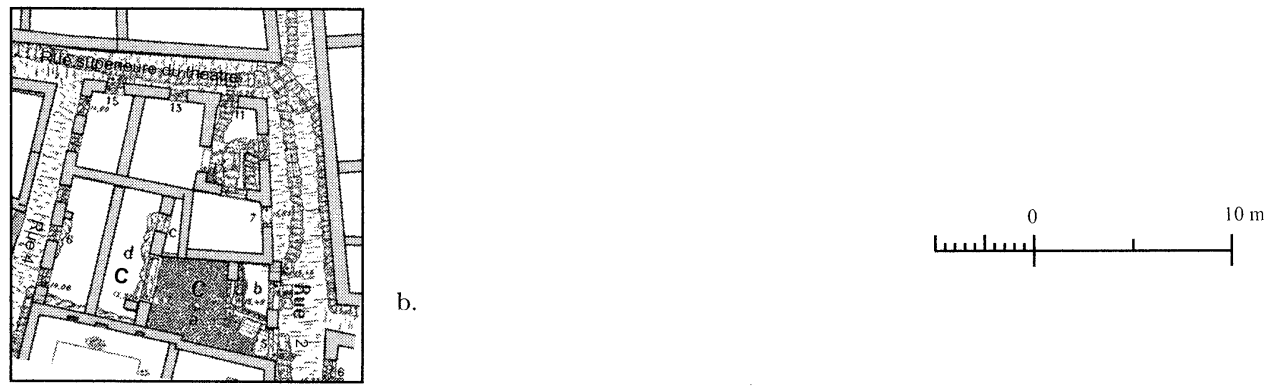

b.

Figure 11 | Mixed housing of all social classes at Late Hellenistic Delos (from Trümper 2005, p. 124).

By the transitional era of the final two centuries BC, between Hellenistic and Roman times, urban fabrics begin to resemble those of many Early Modern European towns, with many gradations along a vast cline from the hyper-rich multi-courted villas, through middle-class traditional-sized homes, then to the lower classes in small to very small apartments or tiny homes, or even above shops, but all living side by side and even in sublet sectors of elaborate house blocks. The cosmopolitan, commercial and one might now reasonably say, 'globalized' port-town of Delos (fig. II) provides an excellent example of such an urban fabric (Trümper 2005).

However, one more positive sign of social change which is perhaps marked in Romanera Greek houses is a rise in the status of women: Nevett (I992) has recently interpreted the innovation of double access to houses as marking a relaxation in the seclusion of the family, and especially of women, in Greek society. 


\section{Bibliographical references}

\section{Bintliff, John (1994)}

"Territorial Behaviour and the Natural History of the Greek Polis", in: Eckart Olshausen and Holger Sonnabend (eds.), Stuttgarter Kolloquium zur Historischen Geographie des Altertums 4, Amsterdam, pp. 207-249, plates I9-73.

Bintliff, John (2012)

The Complete Archaeology of Greece, Oxford and New York.

Cahill, Nicholas (2002)

Household and City Organization at Olynthus, New Haven and London.

Étienne, Roland, Müller, Christel, and Prost, Francis (2000)

Archéologie Historique de la Grèce Antique, Paris.

Haggis, Donald et al. (2007)

"Excavations at Azoria, 2003-2004, Part I", in: Hesperia 76, pp. 243-32I.

Hansen, Mogens (2004)

"The Concept of the Consumption City Applied to the Greek Polis", in: Thomas Nielsen (ed.), Once Again: Studies in the Ancient Greek Polis, Stuttgart, pp. 9-47.

Hillier, Bill (1996)

Space is the Machine. A Configurational Theory of Architecture, Cambridge.

Hillier, Bill, and Hanson, Julienne (1984)

The Social Logic of Space, Cambridge.

Jameson, Michael (1990)

"Domestic Space in the Greek City-State", in: Susan Kent (ed.), Domestic Architecture and the Use of Space, Cambridge, pp. 92-II3.

Jameson, Michael (1990a)

"Private Space and the Greek City", in: Oswyn Murray and Simon Price (eds.), The Greek City from Homer to Alexander, Oxford, pp. I7I-I95.

\section{Kent, Susan (1990)}

"Activity Areas and Architecture: An Interdisciplinary View of the Relationship Between the Use of Space and Domestic Built Environments", in: Susan Kent (ed.), Domestic Architecture and the Use of Space, Cambridge, pp. I-8.

\section{Kirsten, Ernst (1956)}

Die griechische Polis als historisch-geographisches Problem des Mittelmeerraumes, Bonn.

\section{Lang, Franziska (1996)}

Archaische Siedlungen in Griechenland: Struktur und Entwicklung, Berlin.

Lang, Franziska (2005)

"Structural Change in Archaic Greek Housing", in: Bradley Ault and Lisa Nevett (eds.), Ancient Greek Houses and Households, Philadelphia, pp. I2-35. 
Lohmann, Hans (1993)

Atene. Forschungen zu Siedlungs- und Wirtschaftsstruktur des klassischen Attika, Cologne.

Mazarakis-Ainian, Alexandros (1997)

From Rulers' Dwellings to Temples, Jönsered.

Morris, Ian (1987)

Burial and Ancient Society. The Rise of the Greek City-State, Cambridge.

Morris, Ian (I99I)

"The Early Polis as City and State", in: John Rich and Andrew Wallace-Hadrill (eds.), City and Countryside in the Ancient World, London, pp. 25-27.

Morris, Ian (2000)

Archaeology as Cultural History, Oxford.

Nevett, Lisa (1999)

House and Society in the Ancient Greek World, Cambridge.

Nevett, Lisa (2002)

"Continuity and Change in Greek Households under Roman Rule", in: Erik Ostenfeld (ed.), Greek Romans and Roman Greeks, Aarhus, pp. 8I-97.

Ruschenbusch, Eberhard (1985)

"Die Zahl der griechischen Staaten und Arealgröße und Bürgerzahl der 'Normalpolis', in: Zeitschrift für Papyrologie und Epigraphik 59, pp. 253-263.

Snodgrass, Anthony (1980)

Archaic Greece: The Age of Experiment, London.

Snodgrass, Anthony (I99I)

"Archaeology and the Study of the Greek City", in: John Rich and Andrew Wallace-Hadrill (eds.), City and Country in the Ancient World, London, pp. I-23.

Snodgrass, Anthony (1993)

“The 'Hoplite Reform' Revisited”, in: Dialogues d'Histoire Ancienne i9, pp. 47-6I.

Trümper, Monika (2005)

"Modest Housing in Late Hellenistic Delos", in: Bradley Ault and Lisa Nevett (eds.), Ancient Greek Houses and Households, Philadelphia, pp. II9-I39.

Tsakirgis, Barbara (2005)

"Living and Working around the Athenian Agora: A Preliminary Case-Study of Three Houses", in: Bradley Ault and Lisa Nevett (eds.), Ancient Greek Houses and Households, Philadelphia, pp. 67-82.

Westgate, Ruth (2007)

"House and Society in Classical and Hellenistic Crete", in: American Journal of Archaeology 111, pp. 423-457.

Whitley, James (200I)

The Archaeology of Ancient Greece, Cambridge. 